\title{
Aging-Related Differences in the Resolution of Ambiguity from Case Marker Deletions in a Verb-Final Language
}

\author{
Jee Eun Sunga, Seunghun J. Lee ${ }^{b, c}$, Bora Eom ${ }^{a}$ \\ ${ }^{a}$ Department of Communication Disorders, Ewha Womans University, Seoul, Korea \\ ${ }^{b}$ Department of Psychology and Linguistics, International Christian University, Tokyo, Japan \\ 'MER Mathivha Centre for African Languages, Arts and Culture at the University of Venda, Thohoyandou, South Africa
}

Correspondence: Jee Eun Sung, PhD

Department of Communication Disorders, Ewha Womans University, 52 Ewhayeodae-gil, Seodamun-gu, Seoul 03760, Korea

Tel: $+82-2-3277-2208$

Fax: +82-2-3277-2122

E-mail: jeesung@ewha.ac.kr

Received: July 5, 2019

Revised: August 20, 2019

Accepted: August 24, 2019

This work was supported by the National Research Foundation of Korea Grant funded by the Korean Government (No. NRF-2017S1A2A2038375).

\begin{abstract}
Objectives: This study investigated how age differences impact the resolution of syntactic ambiguities arising through the manipulation of verb voice types and the number of noun phrases (NPs) in stimuli sets. The stimuli consisted of ambiguous sentences that we created by deleting case markers in Korean sentences. We examined resolution strategies from the viewpoint of the nominative-initial preference. Methods: A total of 105 Korean-speaking individuals participated in the study (young adults 49, old adults 56). We manipulated the number of NPs (1 vs. 2) and the verb voice types (active vs. passive) in morphologically ambiguous sentences with NPs that had no case markers. We administered a picture-selection task to examine this nominative-initial preference. Results: We found significant differences in the use of the nominative-initial strategy between the two age groups. Younger adults consistently demonstrated a preference for the nominative-initial strategy across conditions. In contrast, elderly adults presented less preference for the nominative-initial strategy than the younger adults. Conclusion: These findings indicate that elderly adults performed significantly differently in the engagement of the more frequently used syntactic template-based strategy (nominative-initial strategy) than younger adults when resolving syntactic ambiguity. The differences between the age groups in ambiguity resolution strategy may explain aging-related declines in sentence comprehension abilities.
\end{abstract}

Keywords: Aging, Syntactic ambiguity, Nominative-initial preference, Verb-final language
Sentence comprehension is a complex process in which listeners and readers absorb linguistic information at multiple levels, including but not limited to syntactic and semantic units. When linguistic information is insufficient in a given context, people encounter ambiguity (Bader, 1997). In auditory sentence comprehension, listeners must employ various strategies to resolve ambiguities and understand the sentences they hear. Psycholinguistic researchers have long sought to identify the underlying reasons for individual differences in ambiguity resolution. The linguistic sources that induce syntactic ambiguities may vary across the languag- es. Some languages, such as English, that focus on word order in syntactic resolution display ambiguities in garden-path sentences that prevent listeners from performing linear processing for comprehension. However, languages such as Korean that has a relative freedom in the word order have different sources from English when processing syntactically ambiguous sentences.

As shown in (A in Box 1), Korean is a verb-final language that overtly case marks noun phrases (NPs) (Sohn, 2001). These NPs can be scrambled as long as predicates are placed at the end of sentences (B in Box 1). Case is not overtly marked in English-type 
languages, which result in a heavy reliance on word order for sentence processing. German, Korean or Japanese, on the other hand, mark syntactic cases with morphologically overt case markers that carry critical linguistic information for syntactic parsing; these languages also exhibit relatively free word ordering (Bader, 1997). The transliteration from Korean follows Yale Romanization (Martin, 1992).

Box 1. Examples of scrambled Korean sentences with overt case markers

\begin{tabular}{|lllll|}
\hline A & Inho-ka & eoje & swuni-lul & mannasseo. \\
& Inho-NOM yesterday & Swuni-ACC & met \\
& 'Yesterday, Inho met Swuni' & & \\
B & Swuni-lul Inho-ka & eoje & mannasseo. \\
& Swuni-ACC Inho-NOM & yesterday & met \\
& 'Yesterday, Inho met Swuni' & & \\
\hline
\end{tabular}

Overt case marking, however, is not obligatory in Korean as shown in (Box 2). In colloquial Korean, if enough contexts are provided, speakers simply drop case markers of NPs because the grammatical relationship between the noun is easily retrievable. Speakers often delete case markers in daily conversation as long as the semantic and syntactic interpretation is possible with a given context without case markers (Yook, 2015). The example (A in Box 2) shows that the accusative case marker is more readily dropped than the nominative case marker. When both case markers are dropped as in (B in Box 2), a specific prosodic pattern is accompanied with the sentence; the first noun Inho '(a personal name)' often ends with a rising intonation.

Box 2. Examples of Korean sentences with case marker deletion

\begin{tabular}{|lllll|}
\hline A & Inho-ka & eoje & Swuni- $\varnothing$ & mannasseo. \\
& Inho-NOM & yesterday & Swuni & met \\
& 'Yesterday, Inho met Swuni' & & \\
B & Inho- $\varnothing$ & eoje & Swuni- $\varnothing$ & mannasseo. \\
& Inho & yesterday & Swuni & met \\
& 'Yesterday, Inho met Swuni' & & \\
\hline
\end{tabular}

It is often possible to delete all case markers when the NPs carry other linguistic cues, such as animacy, to retrieve the thematic roles of NPs in a sentence. For example, Mom- $\varnothing$ rice- $\varnothing$ eat. In this sentence, even without case marking the sentence means 'Mom is eating rice' because the two NPs are semantically irreversible: rice can never be the agent of the sentence. Using the animacy information of NPs, interlocuters can interpret these types of case-mark- er-less sentences. In situations when two NPs are semantically reversible, the meaning of a sentence can become ambiguous in the absence of distinct context in the conversation.

As an SOV language, Korean displays a nominative-initial word order which is regarded as canonical or unmarked (Lee \& Ramsey, 2000; Martin, 1992). Even so, Korean allows non-nominative-initial word order through scrambling, topicalization or focus. While cases are expressed through determiners in German, the case markers in Korean are postpositional particles, inserted immediately following the head noun. Korean also allows scrambled structures with few syntactic constraints, as long as verbs are retained at the ends of sentences (Sohn, 2001).

Although phenomena of case marker deletion is frequently observed in daily conversation, the effects of case marker deletion on sentence comprehension have not been examined through the manipulation of psycholinguistic variables. The current study investigates ambiguity resolution strategies when both case markers are absent and examines how these strategies may differ between young and elderly adults. For our experimental paradigm, we deleted case markers in order to purposefully create ambiguous sentences, which enabled us to examine the degree to which listeners prefer the nominative-initial strategy in Korean when they encounter syntactic ambiguity. The nominative-initial strategy is a strategy whereby listeners process the first NP of a sentence as a nominative irrespective of whether a sentence has one NP or two NPs. This strategy is couched in processing of information under the assumption that listeners treat the first appearance of a NP as a nominative.

In colloquial Korean, speakers often drop case markers (Yoon, 2012), as long as listeners or readers can determine the thematic roles of NPs from the context. When all morphological case markers are absent in a sentence, listeners may need to employ different strategies, such as relying on animacy information, to assign thematic roles. To minimize the animacy effect in sentence processing, we employed a pictogram-based picture selection paradigm to present sentences that had NPs without case markers. We thereby limited the possibilities available to listeners trying to rely on semantic knowledge in thematic role assignment. The task consisted of a limited set of vocabulary, involving three-color humanized symbols (The Blue, The Yellow, and The Black) to describe 
the agent and theme in a picture. This task design made it hard for listeners to utilize top-down semantic cues such as animacy information, where animate NPs are more likely to be parsed as subjects than inanimate NPs. Box 3 presents a Korean sentence with full case-marking that forms the baseline of the current study. Both the subject NP and the object NP are followed by respective case markers.

Box 3. Examples of current experimental stimuli with full case-marking

\begin{tabular}{|lll|}
\hline Kamansayk-i & Phalansayk-ul & ccoch-ta \\
The Black-nom & The Blue-Acc & chase-nf \\
NP1-nom & NP2-acc & Verb \\
'The Black one chases the Blue one' & \\
\hline
\end{tabular}

We modified Box 3 by deleting case markers in order to create syntactic ambiguity: Kamansayk- $\varnothing$ phalansayk- $\varnothing$ ccochta 'The Black- $\varnothing$ The Blue- $\varnothing$ chases'. After playing a stimulus using a speaker on a laptop computer, we asked participants to select one picture out of the two options presented to them, as shown in Figure 1: “The Black chases the Blue." vs. "The Blue chases the Black". We hypothesized that listeners who would select the picture depicting "The Black chases the Blue" processed the ambiguous sentence based on the nominative-initial strategy. Listeners who would select the alternative ("The Blue chases the Black") assigned an accusative case marker to the 1st NP and a nominative case marker to the 2nd NP, meaning they parsed the syntactically ambiguous sentence using the non-nominative-initial strategy. Figure 2 shows the schematic paradigm of the nominative-initial preference rating and its underlying case marking process.

Using this very constrained paradigm enabled us to examine the degree to which listeners relied on the most frequently used syntactic template in Korean, the nominative-initial order (Lee \& Ramsey, 2000; Martin, 1992). Our motivation for examining the nominative-initial preference in Korean came from evidence regarding aging populations. Previous studies consistently reported that elderly adults demonstrated greater difficulties in non-nominative-initial word-order than nominative-initial structures across modalities; including a sentence comprehension task using a pictogram-based sentence-picture paradigm with full case markings (Sung, 2015a; 2017), a sentence production task (Sung, 2015b), and a case marker processing task (Sung, 2017). The consistent findings that, despite the freedom of word order in Korean, normal elderly adults have greater difficulties with non-nominative-initial

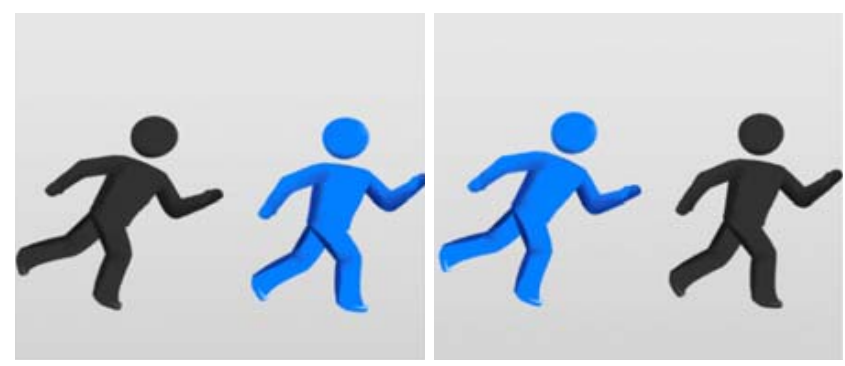

Figure 1. An example of the picture selection task for "The Black chases the Blue".

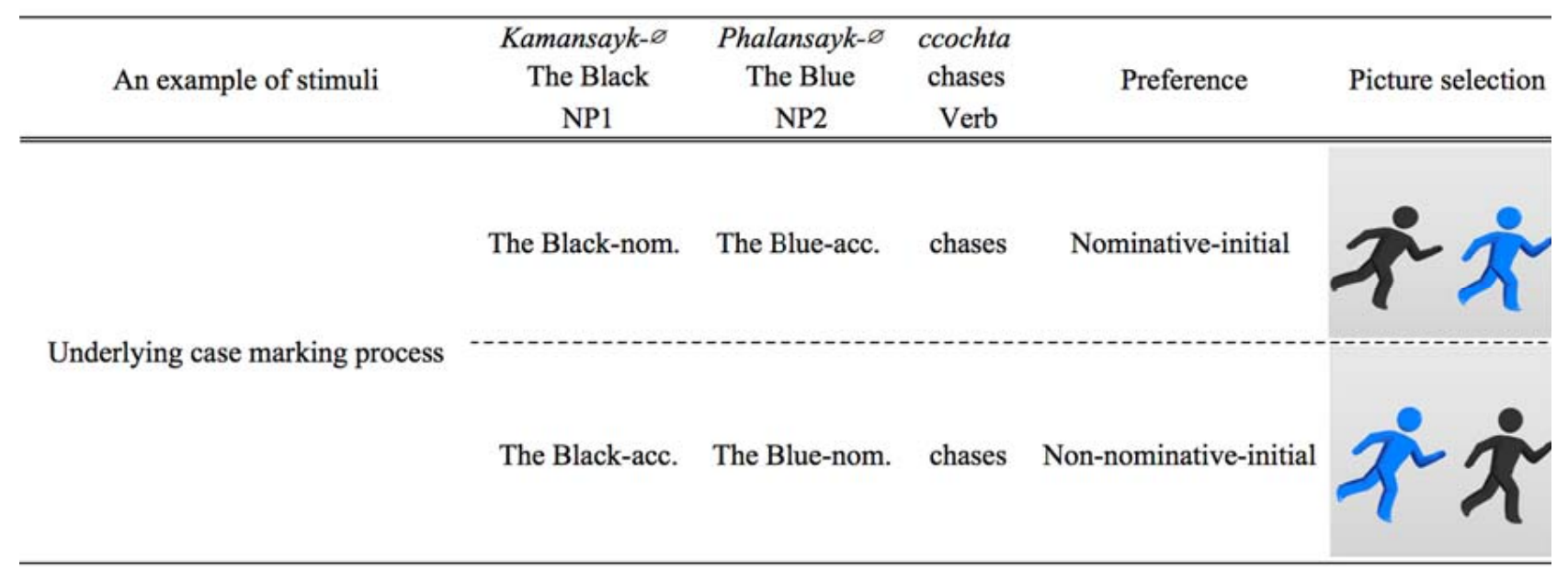

Figure 2. Schematic paradigm of nominative-initial preference ratings. 
structures inspired us to further investigate NP processing strategies and preferences in parsing ambiguous sentences when the case markers are absent.

Because previous studies have showed that Korean-speaking elderly adults have more difficulty comprehending passive sentences than active sentences (Sung, 2015a, 2017), we also manipulated the syntactic voice of sentences to present active and passive verbal forms following the NPs. In Korean, passive verbs are created by affixing passive morphemes after active verbal roots. Since passive verb forms also appear in the final position in Korean sentences, listeners and readers are likely to begin a reanalysis process when they encounter a passive verb in stimuli that have no case markings in the arguments preceding the verb. Cross-linguistically, including in Korean, passive sentences are less frequent than active sentences (cf. Li, 1976; Siewierska, 2013). As such, syntactic parsers tend to activate active constructions first when presented with multiple NPs. However, further along in such sentences when parsers encounter a verb in its passive form, they must revise their analysis and reassign thematic roles to NPs. In Korean passive structures, NPs with nominative case markers take the themes as their thematic roles, while the thematic role of agents are assigned to the NPs with oblique case markers - equivalent to the $b y$-phrase in passive sentences in English. Box 4 provides a passive sentence in Korean with nominative-initial word order: glosses the syntactic case marking (A) and glosses the thematic roles (B).

Box 4. An example of a passive sentence with nominative-initial word order

\begin{tabular}{|llll|}
\hline & The Yellow-ka & The Black-eykey & is chased \\
A & NP1-nom & NP2-obL & Verb-PAss \\
B & NP1-theme & NP2-agent & Verb-pass \\
& 'The Yellow is chased by the Black' & \\
\hline
\end{tabular}

In nominative-initial passive sentences, the order of thematic roles switches from the typical thematic agent-first assignment. However, in passive sentences with non-nominative-initial orders like Box 5, the thematic order follows the canonical agent-first assignment. The syntactic order in Box 5 is not canonical because the non-nominative NP (NP with oblique case marker) is placed prior to the nominative NP: glosses the case marking (A) and glosses the thematic role (B).
Box 5. An example of a passive sentence with non-nominative-initial orders

\begin{tabular}{|llll|}
\hline & The Yellow-eykey & the Black-i & is chased \\
A & NP1-obl & NP2-nom & Verb-pass \\
B & NP1-agent & NP2-theme & Verb-pass \\
& 'The Black is chased by the Yellow' & \\
\hline
\end{tabular}

Manipulating the verb voice types in ambiguous sentences without case markers enabled us to examine the strategies Korean listeners prefer between nominative-initial order activation and agentfirst thematic role assignment when conflicts emerge in the canonicity of the syntactic case marking and thematic role assignment.

We also examined the number of NPs presented prior to the verbs. The number of NPs relates to the information in semantic units associated with verbs. We presented either 1-NP or 2-NP conditions for both active and passive constructions. This manipulation made it possible to examine the nominative-initial strategy based on the number of semantic units. There might be other possibilities to create syntactic ambiguities such as by selectively deleting case markers instead of deleting all of them. However, the current study experimentally manipulated the number of NPs and voice types by deleting all of the case markers to specifically focus on the NP-preference strategy when listeners are challenged to face the extreme condition of case marker deletion.

We predicted that this could produce two different outcomes. First, the 2-NP condition could elicit stronger nominative-initial word order preference than the 1-NP condition. Korean is a prodrop language in which, among syntactic units, the subject is most frequently deleted (Sohn, 2001). This feature may decrease the preference for the nominative-initial strategy under the 1-NP condition. When presented with only one NP, syntactic parsers may process the NP as a verb-internal argument, assigning nonnominative case markers to that NP based on their experience of dropping the subject. Another possibility is that the 2-NP condition could elicit weaker nominative-initial preference than the 1-NP condition. Given that Korean syntactic structures allow both nominative-initial and non-nominative-initial serializations, the presentation of the two NPs may introduce greater interference and competition into thematic and syntactic computations. The interference effects could reduce the effect of the nominative-initial strategy or even produce random effects in the choice of pictures. 
As far as we know, no study has yet examined aging-related differences in NP processing strategies for ambiguous sentences in a verb-final language with a rich case marking system by deleting case markers to induce ambiguity and manipulating the syntactic voice and the number of semantic units. This unique experimental paradigm enabled us to better understand the strategies used by human syntactic parsers. Our specific purpose in this study was to investigate aging-related differences in the use of the nominative-initial strategy when parsing syntactically ambiguous sentences according to the syntactic voice of verbs (active vs. passive) and the number of NPs (1-NP vs. 2-NP) in the sentences.

\section{METHODS}

\section{Participants}

A total of 105 Korean-speaking individuals (male 42; female 63) participated in the study: 49 adults under 40 years old (mean age, $26.51 \pm 5.48$ ) and 56 normal elderly adults (mean age, $65.09 \pm 4.25$ ) (Table 1). We recruited younger adult group with the age criteria from 19-40 and elderly adults with 60-80. All participants provided written consent forms prior to enrolling in the experiment, and the Institutional Review Board of Ewha Womans University (No. 105-1) approved the protocol. All participants were monolingual, right handed Koreans with no history of neurological or psychiatric disorders according to a health screening questionnaire (Christensen, Multhaup, Nordstrom, \& Voss, 1991). We screened their cognitive abilities using the Korean Mini-Mental State Examination (K-MMSE; Kang, Jang, \& Na, 2012), and all showed a normal range of performance on the K-MMSE (age- and education-adjusted scores $>16$ th percentile). There was no significant difference between the groups in years of formal education $\left(F_{(1,103)}=1.403\right.$,

Table 1. Descriptive information on participants

\begin{tabular}{lcl}
\hline & Young adults $(\mathrm{N}=49)$ & Older adults $(\mathrm{N}=56)$ \\
\hline Gender & & \\
Male & 22 & 20 \\
Female & 27 & 36 \\
Age (yr) & $26.51 \pm 5.48(19-38)$ & $65.09 \pm 4.25(60-74)$ \\
Education (yr) & $14.88 \pm 2.17(12-20)$ & $14.16 \pm 2.97(9-23)$ \\
K-MMSE & $29.31 \pm 1.19(24-30)$ & $28.23 \pm 1.51(25-30)$ \\
\hline
\end{tabular}

Values are presented as number or mean \pm SD (range). K-MMSE= Korean Mini-Mental State Examination (Kang, Jang, \& Na, 2012). $p=.238)$. We collected data in one testing session.

\section{Materials}

We developed a picture-selection task by modifying a sentence comprehension task (SCT) (Sung, 2015a, 2017) that originally employed a sentence-picture matching paradigm. We created the humanized pictogram using three color-related vocabulary: 'the Yellow', 'the Black', and 'the Blue' to minimize the influence of topdown semantic knowledge on sentence processing. In this study's picture-selection task, participants listened to a sentence recorded by a professional voice user and selected from two possible options the picture they believed corresponded to the sentence (Figure 1). The picture-selection task (PST) consisted of two syntactic voices (active and passive) and two NP number conditions. Table 2 provides specific examples of each condition.

Participants were administered a total of 24 sentences with 6 items for each condition (Appendix 1). We matched the frequency of the color-word occurrences across conditions and used six verbal stems to create each active construction and its passive counterpart. We pseudo-randomized the order of stimuli presentation to avoid presenting three items from the same condition consecutively. We rated 1 for participant's selections of pictures depicting the 1st NP marked as a nominative and 0 for the selections of pictures of the 1st NP marked with a non-nominative case marker. Table 3 provides specific examples of the ratings for each condition. Outcome measures close to 1 indicated that participants relied more heavily on the nominative-initial strategy when they selected a picture after listening to ambiguous sentences without case markers.

Table 2. Examples of sentence stimuli for each condition

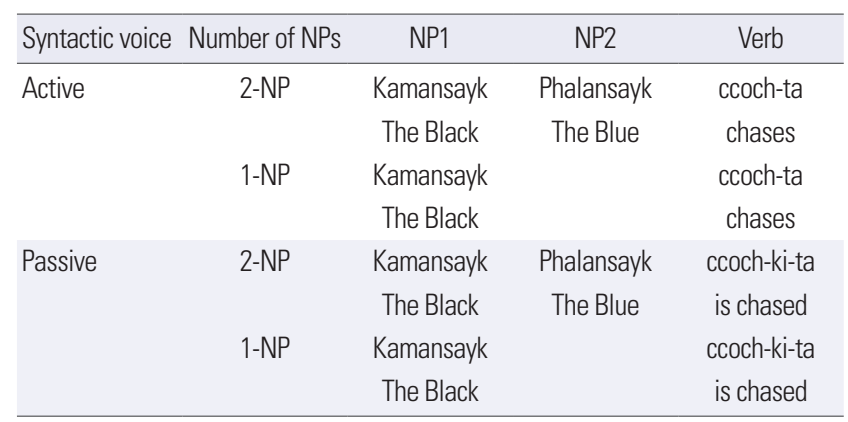

$\mathrm{NP}=$ noun phrase 
Table 3. Examples of the ratings for each condition

\begin{tabular}{|c|c|c|c|c|c|c|}
\hline \multirow{2}{*}{ Syntactic voice } & \multirow{2}{*}{$\begin{array}{l}\text { Number } \\
\text { of NPS }\end{array}$} & \multicolumn{3}{|c|}{ Sentence stimuli } & \multirow{2}{*}{ Selection } & \multirow{2}{*}{ Rating } \\
\hline & & NP1 & NP2 & Verb & & \\
\hline \multirow[t]{4}{*}{ Active } & 2-NP & Kamansayk & Phalansayk & ccoch-ta & The Black chases the Blue & 1 \\
\hline & & The Black & The Blue & chases & The Blue chases the Black & 0 \\
\hline & $1-N P$ & Kamansayk & & ccoch-ta & The Black chases (the Blue) & 1 \\
\hline & & The Black & & chases & The Blue chases (the Black) & 0 \\
\hline \multirow[t]{4}{*}{ Passive } & 2-NP & Kamansayk & Phalansayk & ccoch-ki-ta & The Black is chased by the Blue & 1 \\
\hline & & The Black & The Blue & is chased & The Blue is chased by the Black & 0 \\
\hline & $1-N P$ & Kamansayk & & ccoch-ki-ta & The Black is chased (by the Blue) & 1 \\
\hline & & The Black & & is chased & (The Blue) is chased by the Black & 0 \\
\hline
\end{tabular}

$\mathrm{NP}=$ noun phrase

Table 4. Summary of the results entered into the mixed effects logistic regression model

\begin{tabular}{lcccc}
\hline Predictor & $\begin{array}{c}\text { Coeffi- } \\
\text { cient }\end{array}$ & $\begin{array}{c}\text { SE coeffi- } \\
\text { cient }\end{array}$ & $z$ & $p$-value \\
\hline (intercept) & .9640 & .1806 & 5.337 & $<.0001$ \\
Group (old as a baseline) & 1.8664 & .2612 & 7.145 & $<.0001$ \\
Type (active as a baseline) & 3.1184 & .2612 & 7.145 & $<.0001$ \\
Number of NPs (1-NP as a baseline) & 2.0986 & .1648 & 12.732 & $<.0001$ \\
Type $\times$ Number of NPs & -6.3665 & .2943 & -21.636 & $<.0001$ \\
\hline
\end{tabular}

$\mathrm{NP}=$ noun phrase.

\section{RESULTS}

Since the rating responses on the picture selection task were binary, we used a mixed effects logistic regression model (Jaeger, 2008) with 'Group', 'Sentence Type', and 'Number of NPs' as fixed effects, and 'Participant' as a random intercept. We included effects for the interaction between Sentence Type and Number of NPs. We performed likelihood ratio tests to identify nested models with additional interaction effects. While the interaction between Sentence Type and Number of NPs was significant and thus retained in the final model (model AIC with interaction=3,052; model AIC without interaction $\left.=3,899 ; \chi^{2}(1)=849.0, p<.001\right)$, the fixed effects associated with the Group by Sentence Type interaction (model AIC with interaction=3,053.2; model AIC without interaction $\left.=3,052.0 ; \chi^{2}(1)=.78, p=.38\right)$ and the Group by Number of NPs interaction (model AIC with interaction=3,053.8; model AIC without interaction $=3,052.0 ; \chi^{2}(1)=.15, p=.70$ ) were not significant, and we therefore omitted them from the final model. Table 4 summarizes the statistical results that were entered into the mixed effects logistic regression model, and Figure 3 provides the mean ratings with standard errors.

The intercept was significant, with a log-odds of .9640, $p<.0001$, indicating that participants generally demonstrated nominativeinitial preference under baseline conditions (Group = 'Old', Sentence Type = 'Active', Number of NPs = '1-NP'). The main effect for the group was significant $(\log$-odds $=1.8664, p<.0001)$ with the younger group presenting stronger nominative-initial preference than the elderly group. The sentence type effect was significant (log-odds $=3.1184, p<.0001)$, indicating that the passive voice generated stronger nominative-initial preference than active structures. We found a significant main effect for the number of NPs (log-odds $=2.0986, p<.0001)$, suggesting that listeners in general demonstrated stronger nominative-initial preference in the 2-NP condition than in the 1-NP condition. Finally, the two-way interaction between sentence type and the number of NPs was significant $(\log$-odds $=-6.3665, p<.0001)$. The interaction results suggest that passive structures elicited significantly reduced nominative-initial preference when the two NPs were present, whereas the passive sentences generated greater nominative-initial preference than active types in the 1-NP condition, although the differences between the active and passive were minimal in that condition. Figure 4 shows the two-way interaction.

\section{DISCUSSION \& CONCLUSION}

This study investigated aging-related differences in ambiguity resolution strategies, specifically focusing on the nominative-initial preference and examining whether the use of this strategy dif- 


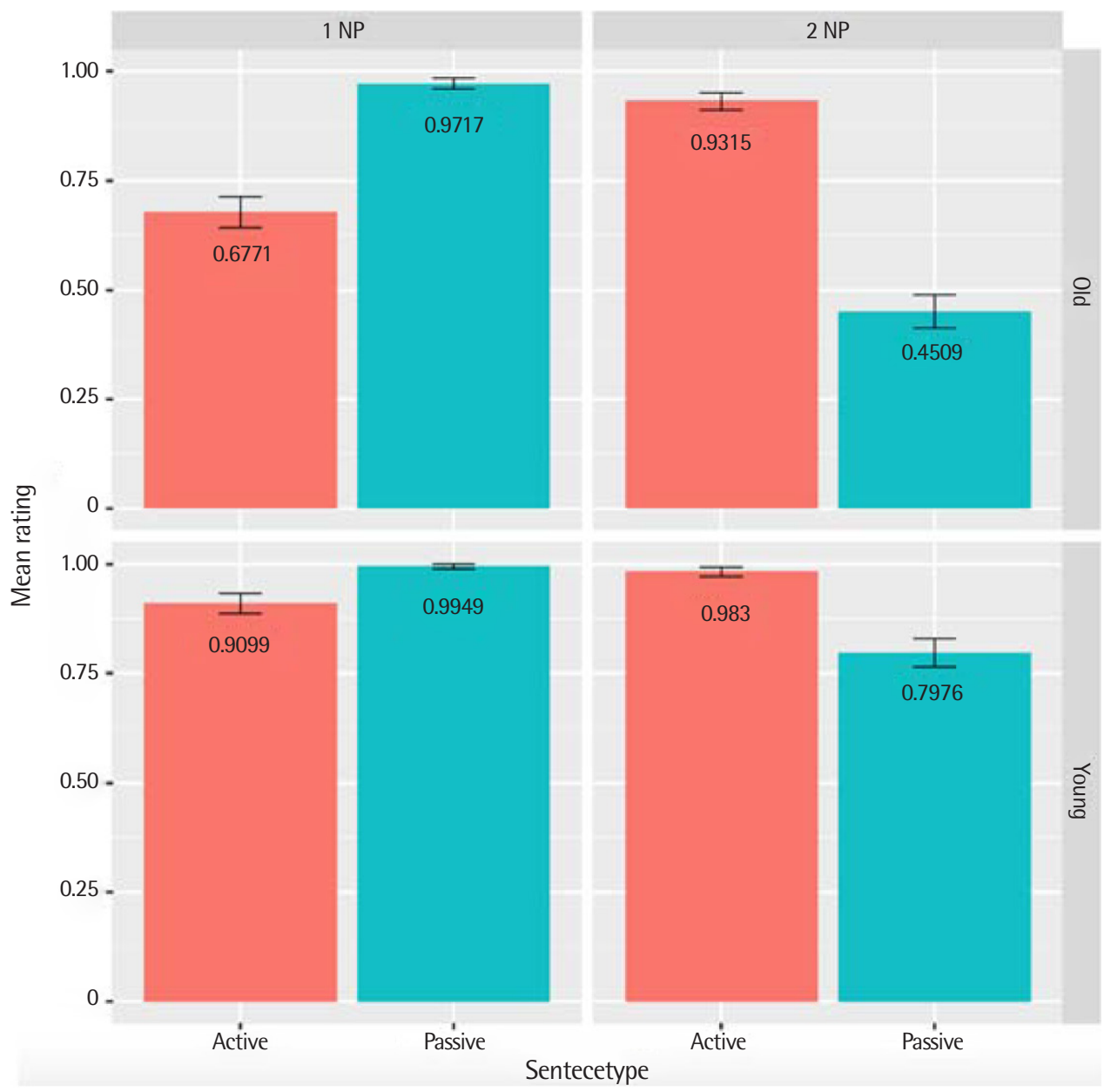

Figure 3. Summary of the mean ratings for each condition in both young and elderly groups.

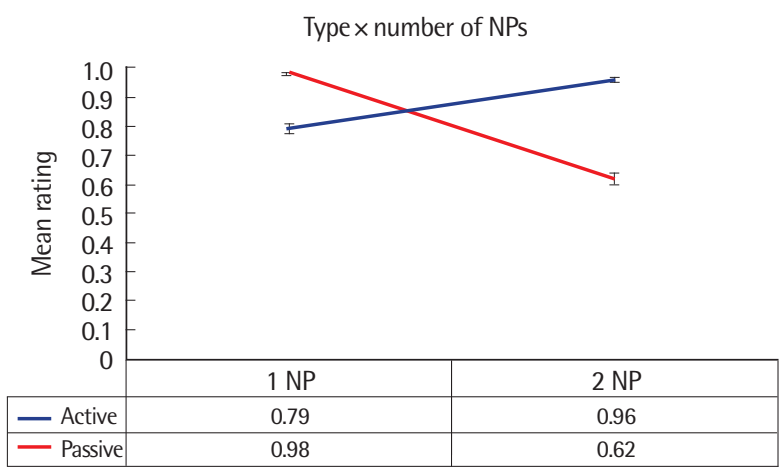

Figure 4. The two-way interaction between sentence type and number of noun phrases (NPs).

fers between young and older groups depending on verb voice and the number of NPs. We found a significant difference in nominative-initial strategy between the age groups; the younger group dem- onstrated a stronger preference for the nominative-initial strategy than the normal elderly group. Younger adults consistently demonstrated a nominative-initial preference across the conditions. In contrast, elderly adults presented significantly lower preference for the nominative-initial strategy than the younger group. Although our analysis showed no interaction between age group and either sentence type or the number of NPs, it should be noted that the elderly group showed chance-level performance with passive structures especially under the 2-NP condition (rating of .45). This chancelevel performance in processing passive structures suggests that elderly adults randomly selected the pictures without engaging a clear strategy. As delineated in the introduction, passive sentences inherently contain conflicting syntactic and thematic structures; nominative-initial syntactic structures have agent-last thematic structures, and vice versa. When listeners rely solely on syntactic 
cues, the nominative-initial strategy emerges, whereas, if they rely on thematic cues, the agent-first strategy emerges. Younger adults showed stronger reliance on syntactic cues with the nominativeinitial strategy even in passive structures (rating of .80). Younger adults who tended to use the nominative-initial strategy to process passive verbs needed to reverse the syntactic order to map it into the underlying thematic structures, given that the NPs with nominative case markers are not agents in passive sentences. This process requires substantial cognitive capacity, because listeners have to inhibit the most frequently activated syntactic template with the nominative NP as an agent and assign the nominative NP to the theme in reverse.

It is well-known that aging affected various domains of cognitive capacity such as working memory and processing resources (Caplan \& Waters, 2005; Caplan, DeDe, Waters, Michaud, \& Tripodis, 2011; Waters \& Caplan, 2001). Older adults with reduced cognitive capacity may encounter greater confusion than younger individuals when processing ambiguous structures without case markers. Older adults' random selection of pictures indicates that they did not rely on any specific strategy - neither nominativeinitial nor agent-first - to resolve syntactic ambiguity, especially in passive sentences. The lack of a clear syntactic or thematic strategy in processing passive sentences may explain elderly adults' less accurate comprehension of passive sentences as opposed to active ones in previous studies (Sung, 2015a, 2017). Previous studies consistently reported that elderly adults performed worse on the passive and non-canonical sentences than active and canonical syntactic structures in Korean. Passive sentences are regarded as more complex syntactic structures due to various reasons as delineated in the introduction. However, the sources of the difficulties and complexity have not been scrutinized in Korean sentence processing with case marking systems. Even when case markers are deleted, the complexity effects emerged given that elderly adults demonstrated different strategies in resolving ambiguities of passive sentences. Thus, this study provides a piece of evidence regarding the strategic mechanisms underlying aging adults' difficulties in processing passive sentences.

We found that verb voice had a significant positive effect (logodds $=3.1184$ ), indicating that passive types elicited generally higher ratings than active. However, we must interpret this main effect with caution given that the type of sentence interacts with the number of NPs. Furthermore, although the three-way interaction was significant, the elderly adults performed at the chance level in the 2-NP passive condition, mainly driving the source of the two-way interaction between the type and number of NPs. A visual inspection of Figure 1 and the descriptive statistics reveals that young adult ratings ranged from .80 to .99 , demonstrating a strong nominative-initial preference across the board. In contrast, the numerical trend follows the hypothesis that elderly adults employed different strategies than younger adults especially for passive sentences, resulting in a chance-level performance in the passive condition. Future studies should investigate this pattern further and examine these effects not only using picture-selection tasks, but also measuring online eye-fixation tendencies with reaction time.

The number of NPs also played a role when it came to eliciting differences in the use of the nominative-initial strategy. Listeners, in general, preferred the nominative-initial strategy in the 1-NP condition over the 2-NP condition. As hypothesized in the introduction, when presented with two NPs, listeners were conflicted about which of the two NPs needed to be marked as a nominative. The presentation of two NP may create similarity-based interference effects (e.g., Gordon, Hendrick, \& Johnson, 2004). Gordon and colleagues suggested that when NPs within a sentence have similar properties, the similarity-based interference effects emerge. They found greater processing difficulties in the similar NP condition (e.g., when both subject- and object-NPs have proper names) than in the condition with the different types of NPs (e.g., one NP with a pronoun and another one with a proper name) (Gordon, Hendrick, \& Johnson, 2001, 2004). In our experimental paradigm, we employed a very constrained picture-selection task in which both NPs carried equally reversible and plausible noun properties as agents or themes. In this regard, the similarity-based interference account is one possible explanation for the stronger activation of the more frequent syntactic template when the interference increased under the 2-NP condition.

The flip-side interpretation of the increased use of the nominative-initial strategy in the 2-NP condition over the 1-NP condition is that the 1-NP condition elicited more frequent use of the nonnominative-initial strategy than the 2-NP condition. As hypothesized in the introduction, the pro-drop phenomenon in Korean 
can account for the greater effect of the non-nominative-initial strategy in the 1-NP condition. Korean speakers often delete the subjects, and thus when they are only presented with one NP, they are likely to treat the NP as a verb-internal argument by processing it as non-nominative: an accusative NP in active structures and an oblique (by-phrase) NP in passive structures.

Finally, the two-way interaction between the type and the number of NPs was significant. The main source of the interaction came from significantly reduced nominative-initial preference in passive sentences, especially under the 2-NP condition. These results indicate that when listeners encountered passive verbs at the ends of sentences after the presentation of the two NPs, they more frequently selected a picture that described the 1st NP as performing the action as an agent, by marking it as an oblique case marker based on non-nominative-initial strategy. However, we must interpret the results of the two-way interaction with caution, because the reduced ratings for the nominative-initial preference seemed to be driven by the elderly adults although the three-way interaction was not significant. The younger adults' rating in the 2-NP passive condition was .80, demonstrating a strong nominative-initial preference, whereas the elderly adults' rating for that condition was .45 . As mentioned above, considering the binary response of the rating, . 45 is close to chance-level performance. The chancelevel performance of the elderly adults in the 2-NP passive condition again suggests that they used no specific preference or strategy in selecting pictures when the sentences were ambiguous. As previously explained, the elderly adults' random selection could stem from their reduced cognitive capacities in computing the reassignment of thematic roles in passive sentences with similar, competing NPs.

In summary, this study examined the aging-related differences in nominative-initial preference for ambiguous sentences. We found that elderly adults performed significantly differently than younger adults in the engagement of the more frequently used syntactic template-based strategy (nominative-initial strategy). Specifically, when the final verbs were presented in passive voice, elderly adults did not use the familiar strategy, whereas younger adults still relied on the nominative-initial strategy. Our findings regarding the effects of the number of NPs reflect how the nature of listeners' language systems can also affect ambiguity resolution, given that the pro-drop phenomena seemed to be partially responsible for the significant effects of the number of NPs. We derived another critical interpretation of the results from the similaritybased interference model. Overall, the results suggest that elderly adults with cognitive decline engaged the parsing strategy differently than younger adults who consistently relied on the nominative-initial strategy.

The current study focused on the strategies they preferred to engage to resolve syntactic ambiguity. The age-group based differences in ambiguity resolution strategies may explain the aging-related decline in sentence comprehension abilities found in previous studies. We employed a novel approach to examine the syntactic ambiguity resolution process in aging populations in a verbfinal language by manipulating critical components-deleting case markers and varying verb-voice and NP numbers. Determining whether these findings are generalizable will require additional research that replicates these morphological garden-path effects in other languages with overt case-marking.

In conclusion, this study investigated aging-related differences in syntactic ambiguity resolution strategies by manipulating verb voice types and the number of NPs. We examined the nominativeinitial preference as the baseline strategy for resolving morphological garden-path sentences created by deleting case markers. Younger adults consistently demonstrated a preference for the nominative-initial strategy across conditions. In contrast, elderly adults showed a significantly lower preference for the nominative-initial strategy than the younger adults. These findings indicate that elderly adults performed significantly differently in the engagement of the more frequently used syntactic template-based strategy (nominative-initial strategy) than younger adults when resolving syntactic ambiguity. The differences between the age groups in ambiguity resolution strategy may explain aging-related declines in sentence comprehension abilities. The current findings imply that the garden-path effects may serve as a sensitive measure of agingrelated decline in sentence processing abilities.

\section{REFERENCES}

Bader, M. (1997). Syntactic and morphological contributions to processing subject-object ambiguities. Jena, Germany: University of Jena. 
Caplan, D., DeDe, G., Waters, G., Michaud, J., \& Tripodis, Y. (2011). Effects of age, speed of processing, and working memory on comprehension of sentences with relative clauses. Psychology and Aging, 26(2), 439.

Caplan, D., \& Waters, G. (2005). The relationship between age, processing speed, working memory capacity, and language comprehension. Memory, 13(3-4), 403-413.

Christensen, K. J., Multhaup, K. S., Nordstrom, S. K., \& Voss, K. A. (1991). A new cognitive battery for dementia: Relative severity of deficits in Alzheimer's disease. Developmental Neuropsychology, 7(4), 435-449.

Gordon, P. C., Hendrick, R., \& Johnson, M. (2001). Memory interference during language processing. Journal of Experimental Psychology: Learning, Memory, and Cognition, 27(6), 1411-1423.

Gordon, P. C., Hendrick, R., \& Johnson, M. (2004). Effects of noun phrase type on sentence complexity. Journal of Memory and Language, 51(1), 97114.

Jaeger, T. F. (2008). Categorical data analysis: away from ANOVAs (transformation or not) and towards logit mixed models. Journal of Memory and Language, 59(4), 434-446.

Kang, Y., Jang, S. M., \& Na, D. L (2012). Seoul Neuropsychological Screening Battery (2nd ed.). Seoul: Human Brain Research \& Consulting.

Lee, I., \& Ramsey, S. R. (2000). The Korean language. Albany, NY: State University of New York Press.

Li, C. N. (1976). Subject and topic. New York, NY: Academic Press.
Martin, S. E. (1992). A reference grammar of Korean: a complete guide to the grammar and history of the Korean language. Tokyo: Tuttle Publishing.

Siewierska, A. (2013). Passive constructions. Retrieved from http://wals.info/ chapter/107.

Sohn, H. M. (2001). The Korean language. Cambridge, MA: Cambridge University Press.

Sung, J. E. (2015a). Effects of syntactic structure on sentence comprehension ability as a function of the canonicity of word-order and its relation to working memory capacity in Korean-speaking elderly adults. Communication Sciences \& Disorders, 20(1), 24-33.

Sung, J. E. (2015b). Age-related changes in sentence production abilities and their relation to working-memory capacity: evidence from a verb-final language. PloS One, 10(4), e0119424.

Sung, J. E. (2017). Age-related decline in case-marker processing and its relation to working memory capacity. Journals of Gerontology Series B: Psychological Sciences and Social Sciences, 72(5), 813-820.

Waters, G. S., \& Caplan, D. (2001). Age, working memory, and on-line syntactic processing in sentence comprehension. Psychology and Aging, 16(1), 128-144.

Yook, H. C. (2015). Korean grammar. Retrieved from http://sapporo.kankoku. or.kr/smain.html.

Yoon, J. (2012). Case drop in Korean: its empirical and theoretical investigation. Bloomington, IN: Indiana University. 
Appendix 1. Sentence stimuli

\begin{tabular}{llll}
\hline \multirow{2}{*}{ Syntactic voice } & \multirow{2}{*}{ Verb } & \multicolumn{2}{c}{ Number of noun phrases } \\
\cline { 3 - 4 } Active & 잡다 & 까만색 파란색 잡다 & \multicolumn{1}{c}{ 파란색 잡다 } \\
& 쫓다 & 까만색 노란색 쫓다 & 노란색 쫓다 \\
& 밀다 & 파란색 노란색 밀다 & 노란색 밀다 \\
& 흔들다 & 파란색 까만색 흔들다 & 까만색 흔들다 \\
& 들다 & 노란색 까만색 들다 & 까만색 들다 \\
차다 & 노란색 파란색 차다 & 파란색 차다 \\
assive & 잡히다 & 파란색 까만색 잡히다 & 까만색 잡히다 \\
& 쫓기다 & 노란색 까만색 쫓기다 & 까만색 쫓기다 \\
& 밀리다 & 노란색 파란색 밀리다 & 파란색 밀리다 \\
& 흔들리다 까만색 파란색 흔들리다 & 파란색 흔들리다 \\
& 들리다 & 까만색 노란색 들리다 & 노란색 들리다 \\
차이다 & 파란색 노란색 차이다 & 노란색 차이다 \\
\hline
\end{tabular}




\section{국문초록}

\section{동사후치어에서 형태론적 중의문 해결 과정이 노화에 미치는 영향}

\section{성지은 ${ }^{1} \cdot$ 이승훈 ${ }^{23} \cdot$ 엄보라 ${ }^{1}$}

${ }^{1}$ 이화여자대학교 대학원 언어병리학과, ${ }^{2}$ International Christian University, ${ }^{3} \mathrm{MER}$ Mathivha Centre for African Languages, Arts and Culture at the University of Venda

배경 및 목적: 본 연구의 목적은 한국어의 형태론적 중의문을 해결하는 과정에서 청년층과 노년층 간 차이가 있는지 살펴보는 것이다. 보다 구체적으로, 형태론적 중의문을 형성하는 명사구의 개수(1 vs. 2) 및 동사의 형태(능동형 vs. 피동형)를 조절하였을 때 그림선택 과 제(picture-selection task)에서 청년층과 노년층 간 차이가 유의한지를 살펴보았다. 방법: 한국어를 모국어로 하는 청년층 49 명, 노년층 56 명으로 총 105 명이 본 연구에 참여하였다. 형태론적 중의문은 명사구에서 조사를 생략하여 구성하였으며, 명사구의 개수는 1 개인 조건과 2 개인 조건으로 구분된다. 각 명사구 조건별로 동사의 형태를 능동형과 피동형으로 나누어 제시하였다. 실험자극은 청각적으 로 제시하였으며, 조사가 생략된 중의문을 듣고 명사구를 주격으로 해결하는 선호도(nominative-initial preference)를 파악할 수 있도 록 그림선택 과제를 실시하였다. 결과: 연구 결과, 청년층과 노년층 간 중의문의 명사구를 주격으로 해결하는 선호도에서 유의한 차이 가 나타났다. 청년층은 전반적으로 모든 조건에서 명사구를 주격으로 해결하는 전략을 뚜렷하게 사용한 반면, 노년층은 이러한 선호 도가 청년층에 비해 낮은 것으로 나타났다. 논의 및 결론: 본 연구 결과를 통해 노년층이 중의문을 해결하는 데 있어 청년층에 비해 주 격선호전략을 사용하는 능력이 감퇴되었음을 알 수 있다. 모호한 정보를 처리할 때, 집단 간 전략사용선호도에서 차이가 있다는 점은 노화에 따른 문장이해 능력의 저하가 일어나는 기저와 관련이 있을 수 있으며, 이러한 노화의 기저를 파악하는 데 문장해결 능력 및 전 략에 대한 기초연구가 더욱 이루어질 필요가 있음을 시사한다.

핵심어: 노화, 중의문, 중의성 해결, 주격선호전략

본 논문 또는 저서는 한국연구재단의 지원을 받아 수행된 연구임(No. NRF-2017S1A2A2038375).

\section{ORCID}

성지은(https://orcid.org/0000-0002-1734-0058); 이승훈(https://orcid.org/0000-0001-5634-5583); 엄보라(https://orcid.org/0000-0002-6052-5357) 